\title{
FEATURED FOOD COMMODITIES FOR FOOD SECURITY SUPPORT IN BALI PROVINCE, INDONESIA
}

\author{
Made Antara $^{1^{*}}$, Made Sri Sumarniasih ${ }^{2}$ \\ ${ }^{1}$ Study Program of Agribusiness, Faculty of Agriculture, Udayana University, \\ Denpasar, Bali, Indonesia \\ ${ }^{2}$ Study Program of Agroecotechnology, Faculty of Agriculture, Udayana University, \\ Denpasar, Bali, Indonesia \\ *Corresponding author Email: antara_unud@yahoo.com
}

\begin{abstract}
Food availability in a region is local food production added imported food and food stock in the warehouse logistics agency. While local food production is supported by featured food production in the region. The objectives of the research: (1) Food availability in Bali Province, (2) the level of regional food security in Bali Province, and (3) featured food commodities in Bali Province. The results of the research showed that (1) Food availability in Bali Province namely the availability of carbohydrate source is $202 \mathrm{~kg} / \mathrm{cap} / \mathrm{yr}$, protein is 112 $\mathrm{kg} / \mathrm{cap} / \mathrm{yr}$, vitamins and minerals are $117 \mathrm{~kg} / \mathrm{cap} / \mathrm{yr}$ for 2017, which means it is all beyond the standard FAO food requirements; (2) Bali's regional food security from the perspective of energy availability are guaranteed to be assured, proved by higher energy availability compared to the adequacy for energy; (3) Featured food commodities in Bali Province is rice potential is developed in districts of Jembrana, Tabanan, Badung, Denpasar, Gianyar and Buleleng. Corn, cassava, and peanut potential are developed in districts of Klungkung, Bangli and Karangasem. Soybean in districts of Jembrana, Tabanan, Badung, Gianyar, Klungkung, Denpasar. Peanuts in districts of Bangli, Karangasem and Buleleng, Green bean in districts of Gianyar, Karangasem and Buleleng. Beef food sources potential are developed in all districts in Bali, a source of protein chicken meat in districts of Bangli, Karangasem and Tabanan. Food sources of fruits in districts of Jembrana, Bangli, Karangasem and Buleleng. Vegetables potential are developed in districts of Tabanan, Klungkung and Denpasar to support Bali's regional food security.
\end{abstract}

Keywords: Food Security Featured Food Commodities Bali

http://dx.doi.org/10.21776/ub.agrise.2020.020.2.7

Received 5 September 2019

Accepted 11 April 2020

Available online 30 April 2020

\section{INTRODUCTION}

There are three strategic and political commodities that have recently become the subject of global discussion, namely food, oil and weapons. In terms of food, throughout history, humans have always been confronted with problems of production and procurement to meet their most basic needs. When there is a food crisis, the Malthus doctrine is brought up again. Malthus in 1798 (see also: Jun-Oh, 2008; Agarwal, 2018; Foster, 1998), proposed a theory entitled Essay on the Principle of Population, the point is that population growth would outperform food production growth, unless there were wars, epidemics, disasters nature, and the dangers of hunger which reduce the human population. According to Prabowo (1981), an increase in food production has indeed occurred, especially in developed countries, but developing and emerging countries are the opposite. There seems to be a general consensus that although in some countries there is a food surplus, food insecurity and famine still occur in poor countries, and food will still remain a troubling problem in the future.

Food security (FS) of a country can be interpreted as the ability of the state to meet the food sufficiency of the entire population, including accessibility, stability and continuity of procurement and distribution. Meanwhile, according to the Food Security Agency (2011), the purpose of the FS program is to increase the availability of staple food commodities in sufficient quantities, of adequate quality, affordable by purchasing power and available at all times.

The food security system covers three important aspects, namely availability, distribution and 
consumption at the household level. The government and society have an important role in the food security system. The Provincial Government of Bali through the Food Crops Department of Bali Province (2007) suggests that food security must be built on the ability of local (regional or district) resources to meet national food needs. Until now the ability of local resources in supporting the food security system must still be optimized so that it can be more affordable for the wider community. Ideally in a good food security system there will be a balance between availability and the level of consumption of the people. If there is pure balance (availability is exactly the same as local consumption), then the province is only at the subsistence level. But if there are advantages of consumption, the district has the potential to trade in food commodities in other areas.

The research objectives are: (1) Analyzing the development of food availability in Bali Province; (2) Identifying regional food security levels in Bali Province from an energy perspective; (3) Identifying featured food commodities supporting food security in each district/city in Bali Province, Indonesia.

\section{LITERATURE REVIEW}

\section{Food Security}

In the 1970s food security began to become an international issue. In the early stages, the concept of food security as a translation of the term food security focused on the level of food availability both at national and regional levels, especially grains. This concept arose because of the world food crisis in 1972-1974. Therefore, the food security policy in Indonesia is based on the food supply approach known as FAA (Food Availability Approach) (Food Security Agency, 2011).

The FAA approach does not pay attention to aspects of distribution and access to food. The assumption underlying this approach is that if the food supply is available, (a) the traders will efficiently distribute the food to the entire area; (b) food prices will remain stable at a reasonable level, so that they can be reached by all families. However, despite adequate food availability, some people still suffer from hunger because they do not have enough access to food. This phenomenon is called a paradox hunger. This is what has caused the food availability approach to fail to achieve sustainable food security in several countries.

In the 1990s there was a shift in the concept of food security that was emphasized on access to food at the household and individual levels. The definition of food security that has been widely accepted by both practitioners and academics is "access to all people at all times to enough food for an active and healthy life". The meaning contained in this definition is that everyone at any time has physical and economic access to sufficient food to meet food needs in order to live a productive and healthy life. In the household context, the definition is based on the concept of entitlement or the ability to control food. Indonesia adopted the formulation of food security and stated in the Republic of Indonesia Law Number 7 of 1996 concerning Food. Food security is defined as the condition of fulfilling food for households which is reflected in the availability of sufficient food, both in quantity and quality, safe, evenly distributed and affordable.

Thus the concept of food security is not the same as self-sufficiency (production) of food (especially rice). The focus of food security is that every human being is able to consume food \& nutrition in a balanced manner (obtained from various foods) for good nutritional status. The focus of food selfsufficiency is the production of (commodities) food sufficient to meet domestic needs (no import is needed). Food self-sufficiency is a strategy to realize food security (Jokolelono, 2011).

\section{Featured Commodities}

Mainstay products are products that have been developed in an area based on agroecological suitability (soil and climate) and are the main source of income for local farmers. Conversely, featured products are some of the most profitable mainstay products to be cultivated / developed in an area, have market prospects, are able to increase farmer and family income, have extensive land resource potential, have superior genetic traits and other characteristics, including taste, aroma and shape (Anonim, 1999; Anonim, 2000). According to Papilaya (in Admin, 2006), from the demand side, superior products are products that can drive market demand high enough to both domestic and foreign markets. Conversely, from the supply side, featured products are products that can drive high supply / supply of these products. The criteria for determining superior products themselves are products that have market prospects, have sufficient natural resources, and other superior characteristics, such as area and ease of development.

Determination of regional featured products is one of the key factors for regional economic development. Not all regions are successful in developing superior products in their regions. There is a difference between the method of determining regional featured products established by the district/city government and those determined by banks. Determination of featured products by the District/City Government uses several criteria, namely (i) typical products (eg pondoh salak, tourist attractions); (ii) number of businesses (palm sugar, pottery, leather); (iii) absorb a lot of labor; and (iv) bias towards existing institutions/agencies. Based on these four criteria, products are grouped into three categories, namely high priority (HP), medium priority (MP), and low priority (LP) (Sugiyanto, 2007). However, Bank of Indonesia (2011) uses other methods to determine featured products in the baseline potential survey, which is viewed from five aspects, namely (i) market and marketing aspects; (ii) 
technical and production aspects; (iii) socio-economic and environmental aspects; (iv) management and legal aspects, and (v) financial aspects.

However, it should be remembered that a featured product in an area does not necessarily become featured continuously. Because of changes in demand, community income, tastes, and input-output prices, perhaps products that have excelled in an area in a given year are no longer superior and may appear as excellent products that are new featured products. Therefore, featured products will change along with changes in external factors, namely factors that are not controlled by farmers or entrepreneurs, such as changes in demand that will affect markets and profits, and input-output prices that affect income / profits obtained by farmers/entrepreneurs.

Based on the previous definition, it is known that featured products are actually the mainstay products that have the potential to be developed and bright market prospects. In addition, if developed, can be a source of income for farmers/entrepreneurs and at the same time become the driving force of the regional economy. However, in choosing one of several types of flagship products to become a superior product (Anonim,1999).

\section{RESEARCH METHODS}

\section{Research Location}

The study was conducted in the region of Bali Province, which was determined purposively, based on the consideration that the Province of Bali has the agricultural sector as the second largest sector in the GRDP contribution, with quite varied agricultural characteristics between districts/cities, which are the main food sources of the population Bali.

\section{Types and Sources of Data}

The type of data needed to support this research is quantitative data or in the form of numbers, sourced from secondary sources, such as the Central Bureau of Statistics (CBS) of the Bali Province, the Provincial and District Agriculture Offices, Regional Development Planning Agency of Bali Province and by district/city. Secondary data that will be used in this study include: Area of agricultural land by district/city, population by district/city, level of food consumption, food crop production by district/city, population poultry or poultry meat production, and the population of ruminants / meat production of ruminants. In addition to secondary data, primary data will also be taken from the results of interviews with officials in the agricultural sector and officials who are authorized to deal with food security issues. This data is in the form of information on policies used to sharpen the analysis in this study.

\section{Methods of Data Analysis}

\section{Descriptive Statistics}

Descriptive statistics are used to measure the level of regional food security, namely the availability of regional-level energy compared to the norm of energy sufficiency, with the following formula (see: Purwantini and Ariani, 2000; Purwantini et al., 2001):

$$
K p i=\frac{S P K E_{i}}{(1,2 N K E)}
$$

- $\mathrm{Kpi}=$ Food security level of a region (Tingkat ketahanan pangan suatu wilayah)

- SPKEi = Level of energy availability for consumption, $\mathrm{kcal} / \mathrm{cap} /$ day)(Tingkat ktersediaan energi untuk konsumsi, kkal/kap/hari)

- $\mathrm{NKE}=$ Norm of energy sufficiency (norma kecukupan energi).

Considering the formula and the amount of carbohydrate food contribution to total energy consumption $(\mathrm{K})$, it can be determined the food security status in the region concerned, with the following criteria:

- If $\mathrm{KP}<\mathrm{K} / 1,2$ means it cannot stand (food insecurity),

- If $\mathrm{K} / 1,2<\mathrm{KP}<\mathrm{K}$, meaning that it is food resistant (not prone) less guaranteed,

- If KP> K. means food resistance (not prone) guaranteed,

- $\mathrm{KP}=$ regional food security levels (tingkat ketahanan pangan regional)

- $\mathrm{K}=$ the amount of carbohydrate food contribution to total energy consumption

- 1,2 = Constanta number of provisions (with a note that the excess is $20 \%$ of the minimum adequacy).

\section{Location Quotient (LQ)}

Initially LQ analysis was used to identify the base and non-base sectors in the economy of a region (Hoover, 1975; Bendavid-Val, 1991; Azis, 1994; Isard et al., 1998; Stimson Et al., 2006; Amstrong and Taylor, 2007; Tarigan, 2007; Pendit, 2012). But in its development LQ can be used to identify the featured commodities that have been used by Pranoto (2008), Afnan et al (2016), Putradi (2005), and Setiowati (2010), namely comparing the ability of a region to produce a food commodity with a province the same commodity producer. LQ analysis can be formulated as follows:

$$
L Q=\frac{S_{i} / N_{i}}{S / N}=\frac{S_{i} / S}{N_{i} / N}
$$

Information:

- $\mathrm{LQ}=$ The magnitude of the coefficient of location of commodity food.

- $\mathrm{Si}=$ Amount (production) of food commodities $i$ in each district

- $\mathrm{S}=$ Amount (total production) of food commodities at the district level

- $\mathrm{Ni}=$ Amount (production) of food commodities $i$ at the provincial level

- $\mathrm{N}=$ Amount (total production) of food 
commodity at the Provincial level.

The LQ number gives the following indications:

- LQ>1, shows that commodities $i$ is featured commodity

- $\mathrm{LQ}<1$, shows that commodity $\mathrm{i}$ is not featured commodity

- $\mathrm{LQ}=1$, shows that these commodities can only cover the region itself.

\section{RESULTS AND DISCUSSION}

\section{Development of Food Availability}

Food availability per capita is the amount of food available for one year divided by the population in that year. High per capita food availability suggests a good level of food security from its availability subsystem. Food availability for the last six years in Bali Province is presented in Table 1.

The development of the availability of carbohydrate food sources $(\mathrm{kg} / \mathrm{cap} / \mathrm{year})$ over the past six years (2012-2017) decreased by $-1.9 \%$ per year. This is due to a decrease in the growth of three of the four types of carbohydrate food sources, namely rice, corn and sweet potatoes by $-0.12 \%,-2.52 \%$ and $3.44 \%$ respectively, with the exception of increased availability of cassava an average of $7.10 \%$ per year (Table 1). This means that the rate of population growth is much higher compared to the rate of growth of food production. The speed of Bali's population growth over the past ten six years has reached $2.15 \%$ per year.
The development of animal protein availability is higher than the availability of vegetable protein. The availability of animal protein is $101.55 \mathrm{~kg} / \mathrm{cap} /$ year in 2012 increasing to $107.87 \mathrm{~kg} / \mathrm{cap} /$ year in 2017 or an increase of $2.02 \%$ per year. Whereas vegetable protein availability was $5.34 \mathrm{~kg} / \mathrm{cap} /$ year in 2012 to $4.11 \mathrm{~kg} / \mathrm{cap} / \mathrm{year}$ in 2017 or decreased by $-4.15 \%$ per year. Vegetable proteins sourced from soybean, peanut and green bean plants tend to decrease respectively by $-1.98 \%,-4.52 \%$, and $-3.63 \%$ per year. The decrease in the availability of soybeans, peanuts and green kacang is caused by a decrease in production and an increase in the number of people who consume the three types of Commodity sources of vegetable protein. But the need for soybeans for the tempe and tofu industry is almost $90 \%$ sourced from imported soybeans through Surabaya importers.

The development of the availability of fruits and vegetables in the Province of Bali during the last six years of 2012-2017 tends to increase. The growth of fruit food availability increased by $1.40 \%$ per year, from the availability of $115.51 \mathrm{~kg} / \mathrm{cap} / \mathrm{year}$ in 2012 to $116.66 \mathrm{~kg} / \mathrm{cap} / \mathrm{year}$ in 2017 . This increase was due to an increase in the production of all types of fruits. The availability of vegetable food in general for the past six years 2012-2017 tends to increase by $2.26 \%$ per year, from the availability of $62.17 \mathrm{~kg} / \mathrm{cap} / \mathrm{year}$ in 2012 to $66.45 \mathrm{~kg} / \mathrm{cap} / \mathrm{year}$ in 2017. This increase caused by increased availability of all types of vegetables, namely shallots, tomatoes, chinese cabbage/mustard greens, leaf onions, kale, and other types of vegetables.

Table 1. Development of Availability of Food Commodities in Bali Province (Kg/Cap/Year)

\begin{tabular}{|c|c|c|c|c|c|c|c|}
\hline Type of Food & 2012 & 2013 & 2014 & 2015 & 2016 & 2017 & $\begin{array}{c}+/- \\
\text { (\%/year) }\end{array}$ \\
\hline 1 & 2 & 3 & 4 & 5 & 6 & 7 & 8 \\
\hline Carbohydrate Source & 222,48 & 197,72 & 200,26 & 193,60 & 197,89 & 201,86 & $-1,9$ \\
\hline - Rice & 154,08 & 153,37 & 144,99 & 153,66 & 150,73 & 152,65 & $-0,12$ \\
\hline - Corn & 15,39 & 14,19 & 9,89 & 9,78 & 13,27 & 12,07 & $-2,52$ \\
\hline - Cassava & 36,76 & 15,18 & 32,13 & 21,33 & 23,66 & 24,90 & 7,10 \\
\hline - Sweet potato & 16,25 & 14,98 & 13,25 & 8,83 & 10,23 & 12,24 & $-3,44$ \\
\hline Vegetable Protein Sources & 5,34 & 4,84 & 4,26 & 3,57 & 3.33 & 4,11 & $-4,15$ \\
\hline - Soybeans & 2,01 & 1,83 & 1,99 & 1,75 & 1,62 & 1,78 & $-1,98$ \\
\hline - Peanuts & 2,95 & 2,72 & 2,04 & 1,70 & 1,57 & 2,11 & $-4,52$ \\
\hline - Green beans & 0,38 & 0,29 & 0,23 & 0,12 & 0,14 & 0,22 & $-3,63$ \\
\hline Animal Protein Sources & 101,55 & 111,17 & 111,65 & 105,07 & 127,96 & 107,87 & 2,02 \\
\hline - $\quad$ Beef & 1,93 & 1,89 & 1,87 & 1,49 & 1,74 & 1,72 & $-1,56$ \\
\hline - $\quad$ Pork & 22,47 & 25,16 & 30,62 & 29,08 & 36,05 & 27,79 & 5,94 \\
\hline - $\quad$ Lamb & 0,43 & 0,33 & 0,48 & 0,47 & 0,65 & 0,46 & 5,69 \\
\hline - Buffalo Meat & 0,00 & 0,00 & 0,01 & 0,00 & 0,01 & 0,00 & 14,47 \\
\hline - Non Broiler Chicken & & & & & & & \\
\hline $\begin{array}{l}\text { Meat } \\
\text { Lavino Chicken Meat }\end{array}$ & 0,69 & $\begin{array}{l}0,68 \\
034\end{array}$ & $\begin{array}{l}1,01 \\
0,58\end{array}$ & $\begin{array}{l}0,57 \\
0,37\end{array}$ & $\begin{array}{l}1,39 \\
0,45\end{array}$ & $\begin{array}{l}0,84 \\
0,40\end{array}$ & $\begin{array}{c}21,34 \\
9,19\end{array}$ \\
\hline - Broiler Chicken Meat & $\begin{array}{l}0,34 \\
5,61\end{array}$ & $\begin{array}{l}0,34 \\
6,77\end{array}$ & $\begin{array}{c}0,58 \\
13,12\end{array}$ & 8,76 & $\begin{array}{c}0,45 \\
18,73\end{array}$ & $\begin{array}{c}0,40 \\
10,31\end{array}$ & 30,01 \\
\hline - Duck meat & 0,06 & 0,07 & 0,09 & 0,05 & 0,09 & 0,07 & 11,25 \\
\hline - $\quad$ Milk & 0,04 & 0,03 & 0,03 & - & - & - & - \\
\hline - $\quad$ Fish (Land and Sea) & 59,30 & 65,07 & 53,14 & 52,71 & 56,16 & 55,32 & $-0,87$ \\
\hline - $\quad$ Eggs & 10,68 & 10,82 & 10,69 & 11,56 & 12,70 & 10,92 & 0,83 \\
\hline Sources of Vitamins and & 177,69 & 188,49 & 212,06 & 192,69 & 175,26 & 183,11 & 0,98 \\
\hline
\end{tabular}




\begin{tabular}{|c|c|c|c|c|c|c|c|}
\hline Fruits: & 115,51 & 125,28 & 138,14 & 127,20 & 97,76 & 116,66 & 1,40 \\
\hline - $\quad$ Avocado & 0,50 & 0,55 & 0,47 & 0,50 & 0,52 & 0,49 & 0,19 \\
\hline - $\quad$ Oranges & 31.32 & 34,81 & 23,81 & 31,29 & 16,14 & 27,29 & 6,32 \\
\hline - $\quad$ Mango & 10,41 & 11,00 & 10,08 & 13,10 & 10.50 & 10,76 & 1,98 \\
\hline - $\quad$ Papaya & 3,12 & 2,36 & 2,59 & 1,89 & 1,16 & 2,27 & 3,01 \\
\hline - Banana & 47,62 & 44,91 & 56,18 & 44,10 & 40,54 & 46,02 & 0,67 \\
\hline - $\quad$ Rambutan & 5,99 & 2,91 & 5,58 & 4,89 & 3,53 & 4,48 & 5,41 \\
\hline - $\quad$ Other fruits & 16,55 & 28,74 & 39,44 & 31,43 & 25,36 & 25.35 & 14.25 \\
\hline Vegetables: & 62,17 & 63,21 & 73,91 & 65,49 & 77,49 & 66,45 & 2,26 \\
\hline - $\quad$ Red onion & 2,17 & 1,95 & 2,35 & 2,43 & 4,26 & 2,56 & 9,77 \\
\hline - $\quad$ Tomato & 2,89 & 3,43 & 4,54 & 3,40 & 4,10 & 3,64 & 7,02 \\
\hline - $\quad$ Pet Mustard & 4,78 & 5,87 & 4,65 & 3,40 & 4,78 & 4,56 & 2,23 \\
\hline - $\quad$ Spring onion & 0,36 & 0,24 & 0,37 & 0,30 & 0,30 & 0,30 & 0,70 \\
\hline - $\quad$ Kale & 0,79 & 0,45 & 1,01 & 0,66 & 0,43 & 0,74 & 16,80 \\
\hline - $\quad$ Other vegetables & 51,18 & 51,27 & 60,99 & 55,30 & 63,63 & 54,65 & 2,15 \\
\hline
\end{tabular}

Source of Data: Processed from the data on the production of various food sources, among others CBS of Bali and Regencies/city (Bali in Figures 2012-2016) and Development Planning Agency of Bali Provionsi (Bali Data of Build 2012-2016). The data of 2017 is extrapolated based on data of 2012-2016.

Note: Fruits consist of important and dominant fruits in Bali, namely adpokat, oranges, mangoes, papayas, bananas, and weeds. The other fruits that were recorded were al. grapes, apples, starfruit, duku/langsat/kokosan, durian, water guava, seed guava, jengkol, big orange, mangosteen, markisah/konyal, melinjo, nangka/cempedak, nenas, petai, salak, sawo, sirsak, dan sukun.( see Bali building data, 2016, pl. VII-25). markisah/konyal, melinjo, jackfruit/cempedak, pineapple, petai, salak, sawo, soursop, and breadfruit (see Bali building data 2016, p. VII-25). Vegetables are also an important vegetable dominant in Bali. Namely shallots, tomatoes, chinese cabbage/mustard greens, scallions, and kale. Other products recorded include: garlic, spinach, cantaloupe, beans, red chili, cayenne pepper, mushrooms, kidney beans, long beans, cauliflower, potatoes, cucumber, and cabbage. Conjoined squash, radishes, melons, peppers, watermelon, strawberry, eggplant, tomatoes and carrots (see Bali building data, 2016, p. VII-24).

The availability of per capita food sources of vitamins and minerals especially for vegetables as a whole has increased. According to the Food and Agriculture Organization (FAO), annual per capita fruit consumption needs of $60 \mathrm{~kg}$. Whereas the availability of fruits in Bali Province such as data in Table 1 (avocados, oranges, mangoes, papayas, bananas, rambutans, and other fruits) reached 116.66 $\mathrm{kg} / \mathrm{cap} / \mathrm{year}$ in 2017 , which exceeds the consumption of fruits. According to FAO. So it can be concluded that the availability of per capita food for fruit food is still safe, or is in high mineral food security. While the standard for consumption of vegetables according to $\mathrm{FAO}$ is $73 \mathrm{~kg}$ per capita per year.

Same as in Bali and Indonesia, Kouekam et al. (2018) said that rice is now playing an important role in economic, political and social aspects in production and consumption decisions in Cameroon, and Buea in particular. The diversification of staple food (rice) production could be facilitated by efforts that promote technological change in agricultural production, improved rural infrastructure, and diversification in food demand patterns.

Community food security, not only determined by food availability, but also access to food. Access to affordable and nutritious food is a widely-debated public policy issue in the U.S. Cleary et al. (2018) report that in non-metro (including semi-urban and rural) U.S. areas, poor food access is mostly the result of lack of food stores, and in particular the absence of large ones (e.g., full-line groceries or superstores). Any policy designed to improve food access in nonmetro U.S. areas should recognize that improving stores' profitability is crucial to policy success in the long-run. They adapt an empirical entry model to assess the effectiveness of two types of policies to improve food access - demand-stimulating policies (DSP), such as increases in Supplemental Nutrition Assistance Program dollars, and supply-side policies (SSP), such as subsidies to reduce establishment costs - by estimating the minimum market size needed for one or more large food stores in non-metro U.S. counties to be profitable.

Food Security from the Energy Availability Development Perspective

According to Suhardjo (1996), the status of regional food security can be categorized into three, namely; (1) Not resistant (food insecure); (2) Food resistance (not prone) is less guaranteed; (3) Food security (not prone) is guaranteed. The criteria for food security status are obtained by comparing the availability of energy in the province with the adequacy of energy needed by the normal human body in unit of kcal/cap/day units.

Regional food security status is obtained by comparing the availability of regional energy in $\mathrm{kcal} / \mathrm{cap} / \mathrm{day}$ which is derived from the development of regional energy availability with the energy adequacy needed by the human body. The 
development of energy availability (kcal/cap/day) is processed from Table 1, while the energy adequacy of the human body (kcal/cap/day) refers to Regulation of the Minister of Health No. 75/2013 concerning Recommended Nutritional Adequacy Numbers for Indonesian Nation: Men aged 19-29 years with a body weight of $60 \mathrm{~kg}$ and $168 \mathrm{~cm}$ high require 2,725 kcal of energy per day (maximum energy requirements) (Source: https://beritagar.id/artikel/gaya-hidup/kecukupankalori-penduduk-indonesia-belum-merata). The results of calculation of guides are presented in Table 2.

Table 2 shows that the availability of total carbohydrate and protein energy ( $\mathrm{kcal} / \mathrm{cap} /$ day) is relatively higher compared to the adequacy of energy per capita per day. To find out the level of food security, it is calculated based on the availability and adequacy of food which shows a range of 1.01-1.10 for the last six years. Meanwhile data on energy contribution from food sources of carbohydrates to energy consumption ranges from 0.89 (2012) - 0.81 (2017). The KP coefficient always shows a higher value than the $K$ value, so that based on the criteria of food security level, the status of the regional food security of Bali Province during the period of 2012 2017 is guaranteed food security. Timmer et al. (1983) said that adequate food security to insure against bad harvests, natural disasters, or uncertain world food supplies and prices.

Table 2: Development of Food Security Status from the Energy Availability Perspective in Bali Province in 2012-2017

\begin{tabular}{lrrrrrr}
\hline \multicolumn{1}{c}{ Energy } & \multicolumn{5}{c}{$\begin{array}{c}\text { Development of Bali Regional Food Security Status from } \\
\text { Energy Availability Perspective } \\
\text { (kcal/cap/day) }\end{array}$} \\
& 2012 & 2013 & 2014 & 2015 & 2016 & 2017 \\
Carbohydrate & $2,438.14$ & $2,166.79$ & $2,194.63$ & $2,121.64$ & $2,168.66$ & $2,212.16$ \\
Protein & $1,171.40$ & $1,271.34$ & $1,270.25$ & $1,190.58$ & $1,438.79$ & $1,227.18$ \\
Total Energy & $3,609.53$ & $3,438.14$ & $3,464.88$ & $3,312.22$ & $3,607.45$ & $3,439.34$ \\
Energy adequacy $*$ ) & $2,725.00$ & $2,725.00$ & $2,725.00$ & $2,725.00$ & $2,725.00$ & $2,725.00$ \\
KP & 1.10 & 1.05 & 1.06 & 1.01 & 1.10 & 1.05 \\
K & 0.89 & 0.80 & 0.81 & 0.78 & 0.80 & 0.81 \\
K/1.2 & 0.75 & 0.66 & 0.67 & 0.65 & 0.66 & 0.68 \\
Status & Guarantee & Guarantee & Guarantee & Guaranteed & Guarantee & Guarantee \\
& d Food & d Food & d Food & Food & d Food & d Food \\
& Security & Security & Security & Security & Security & Security \\
\hline
\end{tabular}

Source: The development of Carbohydrate and Protein energy availability is processed from the development of food availability in Bali Province 2011-2017 (kg/cap/year)(Table 1)

Information:

- $\quad \mathrm{KP}=$ Food Security $($ Ketahanan Pangan $)=$ Energy availability $/ 1.2 \times$ energy adequacy

- $\mathrm{KP}$ is the coefficient of regional food security level with the following criteria:

$\circ$ Can not stand (food insecurity), if $\mathrm{KP}<\mathrm{K} / 1,2$

$\circ \quad$ Food resistance (not prone) is less guaranteed, if $\mathrm{K} / 1,2<\mathrm{KP}<\mathrm{K}$

- Food security (not prone) is guaranteed, if $\mathrm{KP}>\mathrm{K}$

- $\mathrm{K}=$ contribution of carbohydrate food to total energy consumption = availability of carbohydrate energy/ energy adequacy

- 1.2 is the determination number (with a note that has been calculated as an excess of $20 \%$ of the minimum adequacy)

- *) Energy adequacy based on Minister of Health Regulation No. 75/2013 concerning Recommended Nutritional Adequacy Numbers for Indonesian Nation: Men aged 19-29 years with a body weight of $60 \mathrm{~kg}$ and $168 \mathrm{~cm}$ high require $2725 \mathrm{kcal}$ of energy per day (maximum energy requirements) (Source: : https://beritagar.id/artikel/gaya-hidup/kecukupan-kalori-penduduk-indonesia-belum-merata)

Guaranteed food security status in succession over the past six years illustrates the seriousness of the Bali Provincial government in maintaining the stability of food supply. However, another interesting data here is the trend of per capita energy availability per day which tends to decline from 2012 to 2017 actually worth watching. Although the energy adequacy rate per capita per day also shows a decreasing trend over the six years, but actually the energy adequacy rate is stable with little fluctuation because basically humans consume the same amount of food every day. With this condition the Bali provincial government is expected to continue to work hard in order to strengthen the regional food security of Bali.

In relation to food security, Pousga et al. (2018) argue that the university could focus its research activities in the area of agricultural extension in order to contribute to improving food consumption at household level and the population welfare, with the 
best utilisation of national funding. Study imply that agricultural higher education has a key role to play to contribute to the achievement of food and nutrition security in the country, and therefore, policy makers should give opportunities and facilities to these institutions.

However Colen et al. (2018) confirm that although income growth in Africa will increase food consumption and lead to more nutritionally diverse diets, it is also associated with excessive intakes of fats and sugars, raising concerns about over in addition to undernutrition. This suggests that incomebased policies can still play a role in the fight against hunger, but that targeted programs are needed to promote nutritionally valuable and healthy diets.

Montalbano et al. (2018) assess link between market chain participation and food security is characterized by conflicting evidence. Their goal is to deal with this issue at different points of the commercialization chain by providing a sound identification strategy using the Uganda World Bank Living Standards Measurement Study-Integrated Surveys on Agriculture (LSMS-ISA) panel data. By looking at the dynamics of farmers' consumption over time and controlling for a variety of household and production characteristics as well as possible confounding factors, their results show that farmers' food security is positively affected by participation in the market chain, irrespective of the choice of outlet. This provides two key messages for policymaking: farmers selling to the market are better off and intermediaries do not hamper food security.

Postharvest loss exacerbates the food insecurity and welfare loss of farming households in developing countries. Tesfaye and Tirivayi (2018) to analyze the impact of improved storage technologies on food and nutrition security and welfare using nationally representative data from Ethiopia. Endogenous switching regression models are employed to control for unobserved heterogeneity. The study finds that the use of improved storage technologies increases dietary diversity and reduces child malnutrition and self-reported food insecurity. They are also finding that non-user households would have experienced these benefits had they used improved storage technologies. Overall, the study suggests that improved storage technologies can enhance food and nutrition security, and could play a key role in alleviating the challenges of feeding a growing population.

The possible implications of global trends such as climate change and resource scarcity on food security are high on the political agendas. While the food sufficiency aspect of food security takes centrestage, the future of food safety and nutritional quality of diets often seems to be taken for granted. Mylona et al. (2018) in their paper builds on the results of a foresight study on EU food safety and nutrition towards 2050 to discuss potential future points of tension for food policy. Increasing food production while using fewer resources and reducing food waste while ensuring food safety are just two examples. Innovation at different levels in the food system will be needed to address future challenges. Fast technology uptake and the launch of new food-related products can put pressure on the ability to deliver timely risk assessments, the scope of which might also need to cover other legitimate factors. Future food policies need to be more sensitive to impacts on food safety and nutrition and health aspects.

\section{Featured Food Commodities Supporting Food Security}

Economic base theory or the theory of comparative advantage with a Location Quotient (LQ) analysis tool can be used to analyze the diversity of economic bases in the form of featured of commodities or sub-sectors or sectors which if developed can be used as a driving force for economic growth and development in a region. By using the LQ formula for two data hierarchy groups, a lower data hierarchy is compared with a higher data hierarchy, it can identify featured commodities that can be developed to support increased food production in a region to meet local food needs and its advantages can be exported to other regions (see Afnan et al., 201t6), so that commodities or subsectors or sectors that are classified as superior can be prioritized in economic development planning in each district in Bali.

\section{Distribution of Featured Food Commodities of Carbohydrates Source}

This section discusses the results of identification of superior food commodities for carbohydrates per district, namely rice, corn, cassava and sweet potatoes, whose data are derived from the production of food commodities per district compared to similar data in Bali Province. The results of this comparison are known as the Location Quotient (LQ) values which are presented in Table 3 .

In Table 3 it appears that in the carbohydrate source food group, rice is a leading commodity spread in most districts of Jembrana, Tabanan, Badung, Gianyar, and Denpasar cities. The proportion of rice production in the five regions ranges from 90 $99 \%$ of the total food production in each region. The high production of rice is caused by the area of rice fields that are relatively wider than other districts. Klungkung and Karangasem districts have cassava as a superior commodity. Klungkung, which is mostly located in Nusa Penida Subdistrict, is indeed a dry area, so that the suitable food there is cassava. Bangli with sweet potato, and Buleleng with corn food.

In general, all districts/cities in Bali have comparative advantages of carbohydrate source commodities. However, districts that have comparative advantages of rice commodities (LQ>1), do not have comparative advantages of corn, cassava 
and sweet potatoes $(\mathrm{LQ}<1)$. In contrast, districts that have comparative advantages in the commodities of corn, cassava and sweet potato (LQ>1), do not have comparative advantages of rice commodities ( $\mathrm{LQ}<1)$. So rice carbohydrate source food commodities can be developed in districts of Jembrana, Tabanan, Badung, Gianyar, Buleleng and Denpasar city. Food commodities of corn carbohydrate sources can be developed in Klungkung, Bangli, Karangasem and Buleleng Districts. Food commodities of cassava carbohydrate sources can be developed in Klungkung, Bangli and Karangasem Districts. While sweet potato carbohydrate source food commodities can be developed in Badung, Bangli, and Karangasem Districts to support food security in Bali Province.

Table 3: Distribution of Featured Food Commodities Source of Carbohydrates per District in Bali Province, Based on Production in 2012-2017

\begin{tabular}{llcccc}
\hline No & Districts/City & \multicolumn{4}{c}{ LQ of Carbohydrate Food Commodities } \\
\cline { 3 - 5 } & & Rice & Coorn & Cassava & Sweet potato \\
\hline 1 & Jembrana & 1,23 & 0,10 & 0,06 & 0,00 \\
2 & Tabanan & 1,21 & 0,35 & 0,12 & 0,03 \\
3 & Badung & 1,11 & 0,03 & 0,35 & 1,52 \\
4 & Gianyar & 1,19 & 0,14 & 0,16 & 0,34 \\
5 & Klungkung & 0,79 & 2,76 & 2,03 & 0,69 \\
6 & Bangli & 0,62 & 1,47 & 1,30 & 6,15 \\
7 & Karangsem & 0,52 & 1,80 & 3,87 & 2,36 \\
8 & Buleleng & 1,00 & 2,62 & 0,84 & 0,02 \\
9 & Denpasar & 1,24 & 0,00 & 0,00 & 0,00 \\
& Bali & 1,00 & 1,00 & 1,00 & 1,00 \\
\hline
\end{tabular}

Source: LQ is calculated based on data on the production of various food commodities in Bali, the data of which are sourced from CBS of Bali, CBS of Districts in Bali, and Data of Building Bali.

Note : LQ $>1 \rightarrow$ featured commodities; LQ $<1 \rightarrow$ not featured commodities.

Distribution of Featured Food Commodities of Vegetable Protein Source

Table 4 shows that the distribution of featured food commodities from soybean vegetable sources is Districts of Jembrana, Tabanan, Badung, Gianyar, Klungkung, and Denpasar. The district which produces food commodities from the source of peanut vegetable protein is three districts, namely Bangli, Karangasem, and Buleleng. Whereas the base area for mung bean producers is in districts of Gianyar, Karangasem and Buleleng. Soybeans and peanuts are foods that are more in demand by farmers in Bali compared to green beans. The planting of soybeans and green beans by farmers is closely related to programs launched by the regional government, so that fluctuations and the tendency of planting these two commodities are not like rice commodities which have become staple commodities, which farmers will surely continue to grow. So to support the food security of vegetable protein sources in Bali, so the Jembrana, Tabanan, Badung, Gianyar, Klungkung, and Denpasar Districts should develop soybean commodities. Bangli, Karangasem and Buleleng Districts should develop peanuts and green beans.

Table 4: Distribution of Featured Food Commodities of Vegetable Protein Sources per Districts in Bali Province, Based on Production in 2012-2017

\begin{tabular}{|c|c|c|c|c|c|}
\hline \multirow[t]{2}{*}{ No } & \multirow[t]{2}{*}{ Districts/City } & \multicolumn{4}{|c|}{ LQ Food Commodities Source of Vegetable Protein } \\
\hline & & Soybean & Peanuts & Green beans & Featured \\
\hline 1 & Jembrana & 2.05 & 0.12 & 0.93 & Soybean \\
\hline 2 & Tabanan & 2.26 & 0.04 & 0.01 & Soybean \\
\hline 3 & Badung & 1.47 & 0.70 & 0.00 & Soybean \\
\hline 4 & Gianyar & 1.61 & 0.46 & 1.18 & Soybean, Green beans \\
\hline 5 & Klungkung & 1.17 & 0.93 & 0.24 & Soybean \\
\hline 6 & Bangli & 0.07 & 1.91 & 0.00 & Peanuts \\
\hline 7 & Karangasem & 0.05 & 1.76 & 1.75 & Peanuts, Green beans \\
\hline 8 & Buleleng & 0.15 & 1.58 & 2.39 & Peanuts, Green beans \\
\hline 9 & Denpasar & 2.31 & 0.00 & 0.00 & Soybean \\
\hline & Bali & 1.00 & 1.00 & 1.00 & \\
\hline
\end{tabular}

Source: LQ is calculated based on data on the production of various food commodities in Bali, the data of which are sourced from CBS of Bali, CBS ny Districts in Bali, and Data of Building Bali. 
Note : LQ $>1 \rightarrow$ featured commodities; LQ $<1 \rightarrow$ not featured commodities.

\section{Distribution of Featured Food Commodity of Animal Protein Source}

Food which is a source of animal protein consists of chicken meat, duck meat, milk, eggs, beef, mutton, pork, buffalo meat and fish. The results of the analysis of featured food commodities for animal protein sources in each district/city are presented in Table 5. Chicken, beef, pork and mutton meat are the dominant commodities that are dominant in most districts/ cities. Therefore, to support food security in Bali Province, the meat source commodity must be developed through the development of livestock. Gianyar district is the region that has the most comparative advantage of producing chicken meat and duck meat as shown by the largest LQ coefficients of 2.72 and 6.41. Milk is a featured commodity in Bangli District which is shown by the LQ coefficient of 3.29 and the only milk producing district in Bali. Besides that Bangli also has pork commodities $(L Q=1.27)$, free-range chicken meat $(\mathrm{LQ}=1.16)$, laying hens $(\mathrm{LQ}=3.42)$, broiler meat $(\mathrm{LQ}=2.39)$ and eggs $(\mathrm{LQ}=3.02)$ as superior commodities. Therefore, the district government needs to develop livestock or livestock that produce meat food to support food security in Bali Province. Klungkung is always recorded with fisheries production as its leading sector $(\mathrm{LQ}=1.86)$, therefore fisheries is very feasible to be developed in Klungkung District.

Table 5: Distribution of Featured Food Commodities of Animal Protein Sources per District in Bali Province, Based on Production in 2012-2017

\begin{tabular}{cll}
\hline No & District/City & \multicolumn{1}{c}{ Featured Food Commodities of Animal Protein Source Based on LQ Value > 1 } \\
\hline 1 & Jembrana & Goat meat, wild chicken meat, broiler chicken meat, duck meat, fish (sea and land) \\
2 & Tabanan & $\begin{array}{l}\text { Pork, goat meat, wild chicken meat, laying chicken meat, broiler chicken meat, duck } \\
\text { meat, eggs }\end{array}$ \\
& & Beef, pork, broken chicken meat, broiler chicken meat, duck meat \\
3 & Badung & Beef, pork, goat meat, wild chicken meat, broiler chicken meat, duck meat, eggs \\
4 & Gianyar & Sea fish \\
5 & Klungkung & Pork meat, wild chicken meat, laying chicken meat, broiled chicken meat, milk, \\
6 & Bangli & eggs \\
7 & Karangsem & Wild chicken meat, laying chicken meat, broiler chicken meat, eggs \\
8 & Buleleng & Beef, pork, goat meat, wild chicken meat \\
9 & Denpasar & Beef, pork, goat meat, fish (land and sea)
\end{tabular}

Distribution of Featured Food Commodity of Vitamins and Minerals Sources

The commodities of fruits and vegetables are of many types and data for each type is limited and sometimes incomplete, so all of these types are only grouped into two, namely the fruits and vegetables group, which is analyzed by LQ value per district. Leading food commodities, a source of vitamins, are fruits found in Jembrana Regency with featured of banana fruit, Gianyar with featured of citrus fruit, Bangli with featured of citrus fruit, Karangasem with featured of zalacca and mango fruits, and Buleleng Regency with featured of grapes, mangoes, mangosteen and rambutan fruits. Therefore, this type of fruit needs to be developed for each of these districts to support food security in Bali Province.

The featured food commodities of mineral sources, namely vegetables which spread in Tabanan District with featured vegetables of cabbage, scallion, carrots, Klungkung Regency with cabbage, and Denpasar City with featured of kale, and cabbage. Planted in rice fields around the city of Denpasar. Therefore, this type of vegetable commodity must be developed in each of these districts to support the food security of vitamin and mineral sources in Bali Province.

\section{CONCLUSIONS AND POLICY RECOMMENDATIONS}

Conclusions

1) The development of food availability in Bali Province, namely carbohydrate food sources are $202 \mathrm{~kg} / \mathrm{cap} /$ year, protein are $112 \mathrm{~kg} / \mathrm{cap} /$ year (vegetable $3 \mathrm{~kg} / \mathrm{cap} / \mathrm{year}$ animal 108 $\mathrm{kg} / \mathrm{cap} /$ year), vitamins and minerals are 117 $\mathrm{kg} /$ cap/year (fruits) and $66 \mathrm{~kg} / \mathrm{cap} / \mathrm{year}$ (vegetables) for 2017, all exceed and approach FAO food requirements, which means the development of food availability in Bali is relatively strong and safe.

2) The availability of total carbohydrate and protein energy (kcal/cap/day) for the last six years (20122017) is higher than the adequacy or energy needs (cal/cap/day), or positive and greater food security (KP) coefficient than one. This shows 
that Bali's regional food security from the perspective of energy availability is Guaranteed Food Resistant.

3) The featured food commodity in the Province of Bali is rice that is potentially developed in Jembrana, Tabanan, Badung, Denpasar, Gianyar, and Buleleng Districts. Corn, cassava and peanuts in Klungkung, Bangli, and Karangasem Districts. Soybeans in Jembrana, Tabanan, Badung, Gianyar, Klungkung, Denpasar Districts. Peanuts in Bangli, Karangasem and Buleleng Districts. Green beans are potential to be developed in Gianyar, Karangasem and Buleleng Districts. Food sources of beef are potential to be developed in all districts in Bali, a source of food for chicken meat protein in Bangli, Karangasem and Tabanan Districts. Fruit food sources in Jembrana, Bangli, Karangasem and Buleleng Districts. Potential vegetables are developed in Tabanan, Klungkung, and Denpasar districts to support Bali's regional food security.

\section{Policy Recommendations}

1) The regional government of Bali Province must maintain and even increase regional food security by increasing the production of various sources of food carbohydrates (plants), vegetable and animal protein (plants and animals), vitamins and minerals (fruits and vegetables).

2) The district government should develop their respective featured food commodities in accordance with the findings in this study.

3) Research needs to be continued regarding strategies to increase Bali's regional food security and mapping featured food commodities supporting regional food security in Bali.

\section{ACKNOWLEDGMENTS}

Thanks acknowledgments to the Minister of Technology Research and Higher Education (MenRistek-Dikti), especially the Directorate of Research and Community Service on research funding through the National Strategy Research Scheme. Rector of Udayana University cq Head of the Research Institutions and Community Service $(L P P M)$ which facilitates the smooth running of this research. Without good of him, this research would not be conducted.

\section{REFERENCES}

Admin. (2006). Maluku Can Have a Leading Agricultural Commodity Brand. On the Website: Featured Commodities.

Agarwal, Prateek. (2018). Malthusian Theory of Population. In Intelligent of Economist. https://www.intelligenteconomist.com/malthusi an-theory. Downloaded August 12, 2018.

Afnan, F; Darsono; Rahayu, W. (2016). The Role of Featured Agricultural Commodities in each District in the Regional Economy of Bantul Regency. In the SEPA junrla: Vol. 13 No.1 September 2016 : 40 - 47 ISSN : 1829-9946.

Amstrong, Harvey and J.Taylor. (2007). Regional Economics and Policy. Third Edition. Balackwell Publishing, Australia.

Anonim. (1999). Information on Resources for Agribusiness Center Facilities and Infrastructure (Commodities of Salak, Orange, Cattle, Pork, Tuna, Mas / Karper). Project Development Section for Bali-Agricultural Facilities and Infrastructure Facilities in Budget Year of 1998/1999. Bali Provincial Department of Agriculture Regional Office.

Anonim. ( 2000). Preparation of the Master Plan and Action Plan of the Mainstay Area and the Production Center of the Bali Province. Development Planning Agency (Bappeda) of Bali Provincial Cooperation with Udayana University Environmental Research Center.

Azis, Iwan J. (1994). Regional Economics and Some of its Applications in Indonesia. Editor: Marsudi Djojodipuro. Publishers Institute of the Faculty of Economics, University of Indonesia, Jakarta.

Bendavid, A. (1974). Regional Economic Analysis for Practitioners, An Introduction to Common Descriptive Methods. Revised Edition. Praeger Publisher, New York, London. 195 p.

Clearly, R., Boranno, A., Chenarides, L., Goetz, S. (2018). Store profitability and public policies to improve food access in non-metro U.S. counties. Food Policy Journal, Volume 75, February 2018, Pages 158-170. Journal homepage: www.elsevier.com/ locate/foodpol.

Colen, L., Melo, P.C, Abdul-Salam, Y., Roberts, D., Mary, S., and Paloma, S.G.Y. (2018). Income elasticities for food, calories and nutrients across Africa: A meta-analysis. Food Policy Volue 77 (2018), pages 116-132. Journal homepage: www.elsevier.com/ locate/foodpol.

Food Security Agencyl. 2011. General Policy on Food Security 2010-2014. Jakarta: Food Security Council.

Food Crops Department of Bali Province. 2007. General Policy of Bali Province Food Security in 2008 - 2013. Denpasar: Department of Food Crop Agriculture, Bali Province.

Foster, J.B. (1998). Malthus' Essay on Population at Age 200 A Marxian View. Montly Review An Independent Socialist magazine. In https://monthlyreview.org/1998/12/01/malthus- 
essay-on-population-at-age-200/. downloaded, August 12, 2018.

Hoover, E.M. (1975). An Introduction to Regional Economics. Alfred A. Knopf, Inc., New York. $395 \mathrm{p}$.

Issard, W.; I.J.Aziz; M.F.Drennan; R.E. Miller; S.Saltzman; and E. Thorbecke.(1998). Methods of Interregional and Regional Analysis. Ashgate Publishing Company, Brookfield USA, Singapore, Sydney. 490 p.

Jokolelono, Eko. 2011. Food and Food Availability. In Central Sulawesi R \& D Media, IV (2), 8889, Desember 2011. ISSN: 1979-5971.

Jun-Oh, Lee. (2008). Malthus' Essay on the Principle of Population and its Historical Impact. Korean Minjok Leadership Academy International Program.

In https://www.zum.de/whkmla/sp/0809/massai/ massai1.html. Downloaded, August 12, 2018.

Kouekam, A.N., Molua, E.L., Akamin, A., and Cynthia J. Mkong, C.M. (2018). "Determinants of Demand for Rice with Implications for PeriUrban Household Food Security in Southwestern Cameroon." Journal of Food Security, vol. 6, no. 2 (2018): 51-54. doi:10.12691/jfs-6-2-1.

Malthus, Thomas. (1798). An Essay on the Principle of Population. Printed for J. Johnson, in St. Paul's Church-Yard, London. Electronic Scholarly Publishing Project, 1998. In http://www.esp.org/books/malthus/population/m althus.pdf.

Montalbano, P., Pietrelli, R., and Salvatici, L. (2018). Participation in the market chain and food security: The case of the Ugandan maize farmers. Food Policy, Volume 76, April 2018, Pages 81-98. Journal homepage: www.elsevier.com/ locate/foodpol.

Mylona, K., Maragkoudakis, P., Miko, L.,Bock, AK., and Ulberth, F. (2018). Viewpoint: Future of food safety and nutrition - Seeking win-wins, coping with trade-offs. Food Policy Journal, Volume 74 (2018) pages 143-146. Journal homepage: www.elsevier.com/ locate/foodpol.

Pendit, Pratiwi. (2012). Determination of Potential Economic Sector in Order to Support Economic Development Planning in Bangli Regency. [Thesis]. Master Program in Economics Study Program, Postgraduate Program, Udayana University. Denpasar.

Regulation of Health Minister No. 75/2013 concerning Recommended Nutritional Adequacy Numbers for Indonesian Nation: Men aged 19-29 years with a body weight of $60 \mathrm{~kg}$ and $168 \mathrm{~cm}$ high require $2725 \mathrm{kcal}$ of energy per day (maximum energy requirements) (Sourse: https://beritagar.id/artikel/gayahidup/kecukupan-kalori-penduduk-indonesiabelum-merata)

Pousga, S., Bello, O., Francis, J.A., and Boly, H. (2018). "Assessing Food and Nutrition Training in Burkina Faso Using the 'Auditing Instrument for Food Security in Higher education (AIFSHE)'.'Journal of Food Security, vol. 6, no. 2 (2018): 67-73. doi: 10.12691/jfs-6-2-3.

Prabowo, D. 1981. The situation of Indonesian Food in an International Perspective. In Prisma Journal No. 10, October 1981, Year X. LP3ES, Jakarta.

Pranoto, E. (2008). Potential of Agricultural Commodity Areas in Supporting Banyumas Agribusiness Based Food Security. Diponegoro University, Semarang.

Purwantini, T.B. dan M. Ariani. (2000). Analysis of Household Food Consumption After the Economic Crisis in West Java Province. Researcher at the Center for Agricultural Social and Economic Research and Development.

Purwantini, T.B., Handewi P.S. R. dan Y. Marisa. (2001). Regional and Household Level Food Security Analysis (Case Study in North Sulawesi Province). Center for Agricultural Socio Economic and Policy Analysis.

Putradi, J. (2005). Comparative Advantages and Impact of Government Policy on Soybean Commodities in Badung Regency. Postgraduate Program of Udayana University. Denpasar.

Setiowati, S.T. 2010. Analysis of Featured Commodities in the Agricultural Sector in Bangli District, Bali Province. Postgraduate Program of Udayana University, Denpasar.

Stimson, R.J., R.R. Stough, and B.H. Roberts. (2006). Regional Economic Development, Analysis and Planning Strategy. Second Edition. SpringerVerlag Publishing, BerlinHeidelberg.

Suhardjo. (1996). Understanding and Thinking Framework for Household Food Security. Paper presented at the Workshop on Household Food Security, 20 - 30 May 1996, Yogyakarta.

Tarigan, R. (2005). Regional Economics Theory and Applications (Revised Edition). PT Bumi Aksara. Jakarta.

Tesfaye, W., and Tirivayi, N. (2018). The impacts of postharvest storage innovations on food security and welfare in Ethiopia. Food Policy Journal, Volume 75, February 2018, Pages 52-67. https://doi.org/10.1016/j.foodpol.2018.01.004.

Timmer, C.P., Falcon, W.P, and Pearson, S.R. (1983). Food Policy Analysis. Published by World 
Bank, The John Hopkins University Press, Baltimore and London.

Republic of Indonesia Law Number 7 of 1996 concerning Food.

Sugiyanto, C. (2007). Strategies for Preparing of Regional Featured Commodities. On the google.com Website: Featured Commodities. 